\title{
Physical and Chemical Properties of Native and Fully Pregelatinized Cassava Starch (Manihot esculenta Crantz)
}

\author{
I Gusti Ngurah Agung Dewantara Putra ${ }^{1,2}$, Retno Murwanti ${ }^{1}$, Abdul \\ Rohman $^{1}$, T.N. Saifullah Sulaiman ${ }^{1 *}$
}

\begin{abstract}
1 Faculty of Pharmacy, Gadjah Mada University, Skip Utara 55281, Yogyakarta

2 Department of Pharmacy, Faculty of Mathematics and Natural Sciences, Udayana University. Bali

Submitted: 22-06-2018

Revised: $10-07-2018$

Accepted: 25-08-2018

*Corresponding author

T.N. Saifullah Sulaiman

Email:

tn.saifullah@gmail.com
\end{abstract}

\begin{abstract}
Starch is widely used as an excipient in pharmaceutical formulations because it is inert and it can be mixed with drugs without any chemical reactions. This study was aimed to develop and to characterize the physical and chemical properties of cassava starch fully pregelatinized (CSFP) and native cassava starch (Manihot esculenta Crantz) (NCS). Organoleptic properties, $\mathrm{pH}$, ash content, shrink drying, macroscopic and microscopic analyses, amylose and amylopectin content, bulk and tapped density, the angle of repose and flow rate were physically evaluated for both type of cassava starch. Fourier transform infrared spectroscopy (FT-IR), scanning electron microscopy (SEM), energy-dispersive $\mathrm{x}$-ray spectroscopy (EDS), and differential scanning calorimetry (DSC) were used to characterize and evaluate the chemical properties of the CSFP and NCS. The results of this study indicate that CSFP exhibited different values of those determined parameters compared to that of NCS organoleptic properties i.e, $\mathrm{pH}$, viscosity, ash content, shrink drying, macroscopic and microscopic analyses, amylose and amylopectin content, bulk and tapped density, angle of repose and flow rate. The measurement results with DSC obtained Tg at NCS of $68.18^{\circ} \mathrm{C}$ while in CSFP there is no $\mathrm{Tg}$ because cassava starch (CS) is fully gelatinized. In conclusion, CSFP as a good profile starch contained a higher amount of amylose with larger particle size and good particle density and viscosity than the natural starch and improve its flow properties and compactibility. CSFP had a noticeable effect on fragility, hardness, disintegration time and percentage of drug release from the tablets produced, that can be developed as a pharmaceutical excipient in development of solid dosage forms (sustain release).
\end{abstract}

Keywords: cassava starch fully pregelatinized, native cassava starch, physical properties, chemical properties, amylose, amylopectin

\section{INTRODUCTION}

Cassava is easy to grow in tropical countries, and Indonesia is a cassava producing country. Cassava contains a high amount of starch, about 42.1\% (Yusuf et al., 2008; Onyango et al., 2013). Judging from the process of making amylum (starch), two types of starch are often used in the pharmaceutical industry, namely native starch and modified starch (Bhardwaj et al., 2000; Siswanto and Soebagyo, 2006). Native starch is a starch produced from plants that has not been physically or chemically modified.

Starch is an abundant reserve polysaccharide in plants. Generally the starch comprises 20\% water soluble portion (amylose) and $80 \%$ of air-insoluble part (amylopectin). Amylose is a straight molecule, consisting of 250-300 D-glucose units and a dose by $\alpha-1,4-$ glucoside bond which tends to cause a helix-like molecule. Amylopectin consists of 1,000 or more units of glucose that are also connected with $\alpha-1,4$ bonds. However, there is also a number of $\alpha-1,6$ bonds present at the branching points. This bond amount is approximately $4 \%$ of all the number of relationships or one for every 25 units of glucose. Amylopectin in the air can form a colloidal solution. When the colloidal content is heated in the past, it is this nature that 
becomes the binder. While amylose has the ability to expand in contact with liquids, it is this property that is used as a crushing agent (Juliano, 1971; Gusnimar, 2003).

Native cassava starch (NCS) is a starch produced from plants, and has not undergone physical or chemical processing. NCS is the starch obtained from Manihot esculenta, Crantz root tuber, the powder is smooth and white.

Modification of physical properties of starch is done by pregelatinized. The purpose of physical modification is to improve its flow properties and compactibility so that it can be used as a binder in direct compression tablets and can reduce glidant and antiadherent use (Yusuf et al., 2008; Onyango et al., 2013). Pregelatinized modification was performed by giving the treatment of an appropriate amount of water and heating at the appropriate temperature (Emami et al., 2004; Anwar et al., 2006). This method produces starch with larger particle size and higher particle density (Adedokun and Itiola, 2011). In pregelatinized starch gelling process occurs due to the addition of proper water and heating causes the starch granules to absorb water, so that the granules expand to form a thick mass (Patel and Patel, 2006).

Pregelatinized starch can be further categorised as partially pregelatinized starch and fully pregelatinized starch (Hadi et al., 2016). Modification of starch into its fully pregelatinized form is usually done using an organic solvent (Piyachomkwan et al., 2002; Olowosulu et al., 2011). Olowosulu (2011) studies on maize starch (MS) and acacia gum (Ac) have been produced using fully and partial pregelatization methods. In this study cassava starch (CSFP) were fully pregelatinized using the method described by the olowosulu (2011). The process of modification was done using organic solvent with the addition of distilled water and then heating above the starch gelatinating temperature to minimise the use of chemical solvents, which is a safer, more efficient and more economical than other methods.

One of the local plants that produce starch that can be modified in this way is cassava starch. In addition to the relatively cheap price, cassava starch is relatively easy to obtain, so potential is used as solid dosage excipients. The high amylopectin content, ie $83 \%$, makes cassava potential used as a binder in the manufacture of pharmaceutical preparations (Juliano, 1971; Gusnimar, 2003).

Starch modification is done by examining if the produced excipients (CSFP) have better physical and chemical properties than NCS. If the physical and chemical properties of the modified starch are sufficient, it can be compressed and used as an excipient in pharmaceutical tablets (Wlodarski et al., 2016).

\section{MATERIALS AND METHODS}

The study used tubers of cassava (Manihot esculenta Crantz) as the basic ingredient to make starch. The cassava was obtained from Banyuning Village in Bali, Indonesia. The starch was prepared using two different methods as follows native starch and fully pregelatinized starch with the addition of distilled water and then heating above the starch gelatinating temperature.

\section{Native starch}

The native cassava starch was made by peeling cassava, and then washing it with distilled water until clean. The cassava was then cut into small pieces and crushed using a blender, and then distilled water $(2: 1[\mathrm{w} / \mathrm{v}])$ was added to the cassava. The mixture was then squeezed and filtered using a flannelette. The results obtained from filtering were precipitated for $48 \mathrm{~h}$. The resulting supernatant fluid was then removed, and the precipitate was washed with distilled water until a cleaner starch precipitate was obtained. Next, the precipitate was dried in an oven at $3^{\circ} \mathrm{C}$ for $24 \mathrm{~h}$, and then crushed and sieved using a 100-mesh sieve (Bhardwaj et al., 2000; Siswanto and Soebagyo, 2006).

\section{Fully pregelatinized starch}

The fully pregelatinized cassava starch was made with a starch: distilled water ratio of 1:1 (b/v). The mixture was then stirred until a homogenous suspension was formed. The suspension was heated with water vapour at a temperature $80^{\circ} \mathrm{C}$ in a drum, which was closed for $15 \mathrm{~min}$, until gelatinization occurred. The pregelatinized starch was then dried in an oven at $50^{\circ} \mathrm{C}$ or $48 \mathrm{~h}$. Once dried, it was sieved using a 20-mesh sieve (Table I). (Emami et al., 2004; Anwar et al., 2006; Hastuti, 2009; Mariyani et al., 2012; Yusif et al., 2016). 
Table I. Condition of modification process

\begin{tabular}{cc}
\hline Parameter & Process conditions \\
\hline Fully pregelatinized temperature & $80^{\circ} \mathrm{C}$ \\
Heating time & $15 \mathrm{~min}$ \\
Oven temperature & $50^{\circ} \mathrm{C}$ \\
Oven time & $48 \mathrm{~h}$ \\
\hline
\end{tabular}

\section{Physical and chemical properties of the native and fully pregelatinized cassava starch \\ Organoleptic properties}

A panel of 20 tasters consisting of staff and students from Udayana University were used to evaluate the sensitivity of the NCS and the CSFP. The panellists were selected based on their familiarity with the sensory qualities of starch, and the samples were evaluated at room temperature $\left(30 \pm 2^{\circ} \mathrm{C}\right)$. A three-point hedonic scale was used to evaluate colour, taste and smell. The panellists were given water to rinse their mouths between evaluations (Kemp et al., 2009; Sholihah and Noer, 2014). All of the experiments were performed using protocols approved by the University Ethics Committee (protocol number 2018.03.1.0672).

\section{Bulk density and tapped density}

A-10 g quantity of the powder sample was placed in a $50 \mathrm{~mL}$ clean, dry measuring cylinder and the volume, $V_{0}$, occupied by the sample without tapping was determined. After 500 manual taps, the occupied volume was found to be $V_{500}$. The bulk and tapped densities were calculated as the ratio of the weight and volume of the sample ( $V_{0}$ and $V_{500}$, respectively) (Carstensen et al., 1997; Achor et al., 2015).

\section{Determination of iodine and $\mathrm{pH}$ tests}

Iodine and $\mathrm{pH}$ tests were conducted in accordance with the United States Pharmacopeia specifications (United States Pharmacopeial Convention, 2014).

\section{Shrink drying}

For shrink drying, some of the starch was incorporated into the moisture balance set at $105^{\circ} \mathrm{C}$ for an automatic time, and then the weight was accurately weighed until constant (Eckelman, 1998; Piotrowski et al., 2014; Krisyanella et al., 2017).

\section{Measurement of viscosity of the starch}

Viscosity determinations for the native cassava starch and cassava starch fully pregelatinized were carried out on a Brookfield digital viscometer using spindle No 4. The viscosity of in situ gelling solutions was measured at different angular velocities at a temperature of $37^{\circ} \mathrm{C}$. A typical run comprised changing of the angular velocity from 0.0 to 100 $\mathrm{rpm}$. The averages of two readings were used to calculate the viscosity (Shastri et al., 2010; Hareesh et al., 2012).

\section{Solubility}

With semi micro balances as much as $0.01 \mathrm{mg}$ of the starch was added to $1 \mathrm{~L}$ of cold water, and then stirred. Next, the solubility of the sample was determined. This step was repeated by replacing the water with 95\% alcohol (Qazi et.al., 2014; Parwiyanti et al., 2015).

\section{Microscopic and Macroscopic Properties}

The starch granule shapes were observed and photographed using an optical microscope (CX 31, Olympus ${ }^{\circledR}$ ) and stratified sieves with the following meshes 20, 40, 60 and 80 (Abdorreza et al., 2012; Bestari et al., 2016).

\section{FT-IR spectra}

The infrared spectra of the native and pregelatinized cassava starch samples were recorded with a Fourier transform infrared (FTIR) spectrophotometer (JASCO FT-IR-4200 type A model) using potassium bromide pellets format mid infrared region of $400-4000 \mathrm{~cm}^{-1}$ (Fanani et al., 2010).

\section{Ash content}

The ash content was evaluated using a furnace method with a temperature of $550^{\circ} \mathrm{C}$ (Horwitz and AOAC International, 2006). 


\section{Flow rate and angle of repose}

The flow time test and the silent angle test were used to determine the flow rate and angle of repose, respectively. The flow time was done using the funnel method (Dreu et al., 2016).

\section{Amylose and amylopectin content}

The amylose content was determined using the method described by Williams (1958). The starch samples $(20 \mathrm{mg})$ were weighed and placed into a $50 \mathrm{~mL}$ or $100 \mathrm{~mL}$ beaker. Furthermore, a- $10 \mathrm{~mL}$ of $\mathrm{KOH}$ solution $0.5 \mathrm{~N}$ $(28.055 \mathrm{~g} / \mathrm{L})$ was added, and the starch was dispersed with a stirring rod or a magnetic stirring bar for $5 \mathrm{~min}$, or until fully dispersed. Although most starch samples disperse readily, a "difficult" sample may take as long as $20 \mathrm{~min}$ to $30 \mathrm{~min}$ to disperse. The dispersed samples were transferred into $100 \mathrm{~mL}$ volumetric flasks and diluted to the mark with distilled water with careful rinsing of the beaker. An aliquot of the test starch solution $(10 \mathrm{~mL})$ was pipetted into a $50 \mathrm{~mL}$ volumetric flask, and $5 \mathrm{~mL}$ of $0.1 \mathrm{~N} \mathrm{HCl}$ $(8.17 \mathrm{~mL}$ conc. $\mathrm{HCl} / \mathrm{L})$ was added, followed by $0.5 \mathrm{~mL}$ of iodine reagent $\mathrm{B}$. The volume was diluted to $50 \mathrm{~mL}$, and the absorbance of the blue colour was measured at $625 \mathrm{~nm}$ after $5 \mathrm{~min}$. The colour was found to be stable for several hours. Several of the starch dispersions, together with the amylose control, were analysed at intervals up to 30 day after dispersion. In all cases, the stability of the dispersions was verified, indicating that the dispersions can be stored for several days if necessary, before analysis.

\section{Scanning Electron Microscopy (SEM)}

The surface morphology of the native and fully pregelatinized cassava starch was evaluated using SEM (JEOL, JSM-6360, Tokyo, Japan) at X70, X1000 and X2000 magnifications (Gaikwad et al., 2010; Octavia et al., 2017).

\section{Energy-dispersive $X$-ray spectroscopy (EDS)}

EDS (JEOL, JSM-6360, Tokyo, Japan) was produced from X-ray characteristics, i.e. by firing $\mathrm{X}$-rays at the position we want to know the composition. So after firing at the desired position it will appear certain peaks that represent an element contained. With EDS we can also create elemental mapping (element mapping). EDS can be used to analyze the percentages of each element quantitatively (ElMallawany et al., 2008; Agus Cahyana and Ahmad Marzuki, 2014).

\section{Differential Scanning Calorimetry (DSC)}

Thermograms of native and fully pregelatinized cassava starch were performed using DSC-60 (Shimadzu, with software TA60WS Collection Monitor). The system was purged with nitrogen gas at a flow rate of $30 \mathrm{~mL} / \mathrm{min}$. Heating was done from $25^{\circ} \mathrm{C}$ to $300^{\circ} \mathrm{C}$ at a rate of $10^{\circ} \mathrm{C} / \mathrm{min}$ (El-Mallawany et al., 2008; Agus Cahyana and Ahmad Marzuki, 2014).

\section{Preparation of granules}

The wet granulation method of massing and screening was used. $150 \mathrm{~g}$ batches of formulation mixtures of ranitidine $\mathrm{HCl}$, CSFP/NCS, HPMC K4M, and magnesium stearate were mixed. For small batches the ingredients may be mixed in stainless steel bowls or mortars. They were then moistened with PVP $\mathrm{K}-30$ binder solution to yield 2\% w/w, PVP in the final dried granulation. The resulting wet masses were granulated by passing them manually through a 10 mesh sieve, dried oven at $50^{\circ} \mathrm{C}$ for $7 \mathrm{~h}$, and then re-sieved through a 20 mesh sieve. The dried granules were lubricated by using magnesium stearate.

\section{Preparation of tablets}

Quantities (150g) of granules from each batch were compressed into tablets with predetermined loads on single tablet press with a $8 \mathrm{~mm}$ die and flat faced punch assembly. A set of tablets were produced from each pressure. After ejection, the tablets were stored in airtight containers to allow for elastic recovery and hardening, and prevent falsely low yield values before the tablets were subjected to analysis.

\section{RESULTS AND DISCUSSION}

The starch is firstly tested to determine its characteristics and to assess whether the starch used is in accordance with those required in the literature (Table II).

\section{Organoleptic test}

Odor and taste of the native cassava starch (NCS) and cassava starch fully pregelatinized (CSFP), assessed by panellist equal to value 1 that is odourless and no 
taste. While in color, the panelists gave a value of 1 on the cassava starch that is white and the value of 2 for the cassava starch is fully pregelatinized being colored. Organoleptic testing was performed in accordance with the provisions of (Indonesian Pharmacopeia, 2014).

\section{Microscopic and macroscopic analyses}

By observing microscopic and macroscopic characteristics, there was a difference between NCS and CSFP. Microscopically native starch has characteristics according to Indonesian Pharmacopeia (2014) in which the starch formed a slightly rounded, single grain and hilar visible in the middle, while the starch is fully pregelatinized has a multifaceted shape, clustered, hilar and lamella is not visible.

The macroscopic test, the test was done by examining the particle size distribution and the mean diameter $(\mathrm{dr})$, using a multilevel crater where the cassava starch was fully pregelatinized has a larger particle size of 0.428 (Table II) than the native starch and classified as coarse powder (Ansel, 2011).

\section{Determination of ash content}

Ash contents in NCS and CSFP were $0.053 \%$ and $0.073 \%$, respectively (Table II). If these results were compared to the requirements listed on the cassava starch (not more than $0.6 \%$ ), the ash content contained in the starch have already met the Indonesian Pharmacopoeia (2014) standards. All of the starch contained small amounts of inorganic substances, as determined from the residue left behind after the stabbing. Ash of starch mainly contained sodium, potassium, magnesium, and calcium in the form of metal.

\section{Drying losses}

Drying losses are used for the determination of all types of volatile and missing materials under certain conditions (temperature $105^{\circ} \mathrm{C}$ ). Actually, for substances that are thought to contain water as the only volatile ingredient, the determination of water content alone is sufficient. According to Indonesian Pharmacopoeia (2014), it is required that the drying rate is no more than $15 \%$. The result of this study was dried up $13.43 \%$ of NCS and $12.57 \%$ for CSFP (Table I).

\section{Solubility test in water.}

The results of native starch solubility test and fully pregelatinized (one part of starch plus 10.000 parts of water) after stirring resulted not soluble starch. The starch was present in the form of compact particles and its molecular tissue was bonded through a hydrogen bond. In cold water, the particles will not dissolve and break. But with the heating, the starch particles will bubble and break. Although the starch consists of a series of hydrophilic carbohydrates, but because the starch is present in the form of compact and dense particles, then the water will be difficult to penetrate. Given the rise in temperature and stirring will produce the energy that weakens the hydrogen bond, so that water can be absorbed by the starch grains and become like a gel.

\section{Solubility test in ethanol.}

Observation of solubility of NCS and CSFP in ethanol (one part of starch plus 10.000 parts of ethanol) was obtained from the result of insoluble starch. As in the water solubility test, ethanol is also difficult to be absorbed by compacting starch particles, but when the dispersion of the starch is heated and stirred it will become a gel.

\section{Viscosity measurement.}

Viscosity determinations for the NCS and CSFP were carried out on a Brookfield digital viscometer. NCS shows the least viscosity (13.15 Pa.s) and CSFP was more (17.6 Pa.s). This says the increase in amylose concentration causes the increase in viscosity of the starch (Table II).

\section{Amylose and amylopectin contents}

Modified starches contained higher amount of amylose than their native form. To make sure there is starch and meets criteria for starch, before and after the modification is done color test with iodine. The characteristic blue-violet color that appears when starch is treated with iodine is due to the formation of the amylose-iodine complex. This color test is sensitive enough to detect even minute amounts of starch in solution 
Table II. Physsical characteristic of native CNES and fully pregelatinized starch

\begin{tabular}{|c|c|c|c|}
\hline Type of Testing & Limit requirements & Native starch & $\begin{array}{l}\text { Fully pregelatinized } \\
\text { starch }\end{array}$ \\
\hline Identification of starch & $\begin{array}{l}\text { Blue color with iodine } \\
\text { reagent } * \text { ) }\end{array}$ & $\begin{array}{l}\text { Blue color with } \\
\text { iodine reagent }\end{array}$ & $\begin{array}{l}\text { Blue color with iodine } \\
\text { reagent }\end{array}$ \\
\hline $\mathrm{pH}$ & $4.5-7 * *)$ & 6.72 & 6.84 \\
\hline Microscopic & $\begin{array}{l}\text { Oval, single grain, } \\
\text { circular hilus } * \text { ) }\end{array}$ & $\begin{array}{l}\text { Oval, single grain, } \\
\text { circular hilus }\end{array}$ & $\begin{array}{l}\text { Rectangular, single, hilus } \\
\text { are invisible }\end{array}$ \\
\hline Macroscopic & Very fine powder $*$ ) & Very fine powder & Coarse powder \\
\hline Average diameter & & 0.085 & 0.428 \\
\hline Ash rate determination (\%) & $<0.6 \% *)$ & $0.053 \%$ & $0.073 \%$ \\
\hline Drying losses (\%) & $<15 \% *)$ & $13.43 \%$ & $12.57 \%$ \\
\hline Solubility test in water & Insoluble *) & Not dissolved & Not dissolved \\
\hline Solubility test in ethanol & Insoluble *) & Not dissolved & Not dissolved \\
\hline $\begin{array}{l}\text { Measurement of viscosity } \\
\text { of the starch }\end{array}$ & & 13.15 Pa.s & 27.6 Pa.s \\
\hline
\end{tabular}

* Indonesia pharmacopoeia V (2014) ** USPNF23

Table III. Amylose and Amylopectin content

\begin{tabular}{llll}
\hline & Parameter*) & NCS & CSFP \\
\hline Amylose & $17-21 \%$ & $23.14 \%$ & $35.02 \%$ \\
Amylopectin & $79-83 \%$ & $76.86 \%$ & $64.98 \%$ \\
\hline
\end{tabular}

*(Williams, P.C, 1958)

(Figure 6). Native starch has $23.14 \%$ amylose content, then it increased to $35.02 \%$ (Table III) by temperature heating $80^{\circ} \mathrm{C}$ for $15 \mathrm{~min}$ (Table I). Amylose is present in the amorphous region, and during modification this region is mostly accessible from amylopectin side chains. Therefore, amylose content changed due to modification and structural difference between amylose and amylopectin. With high amylose content, starch will show high volume expansion and a high degree of flakiness.

\section{pH testing}

The test results of one-way ANOVA $\mathrm{pH}$-native cassava starch, cassava starch fully pregelatinized. In this study, the level of trust $(\alpha)$ used is $5 \%(0.05)$. The significance value of $\mathrm{pH}$ measurement gives a value smaller than $\alpha$ so that the decision becomes rejected $\mathrm{H}_{0}$ i.e. there is a significant difference between native cassava starch, cassava starch fully pregelatinized.

\section{Flow properties}

Material flow properties can be illustrated with parameters of flow velocity and angle of repose. Based on the table 5 indicating that the native cassava starch cannot be calculated the value of the flow velocity and the angle of repose because it cannot flow through the funnel while the pregelatinized fully produced starch can flow through the funnel with a flow rate for $100 \mathrm{~g}$ less than 10s. At the parameters of flow velocity, fully pregelatinized starch has a flow rate of $6.23 \mathrm{~s}$, while for the parameters of the angle of repose, and has angle of repose of 32.570. This indicates that the modified material of the starch produced better flow properties compared to the native starch. Based on the theory, a native starch cannot flow in the funnel due to the small particle size and the number of fines contained in the native starch, causing the electrostatic forces that pull each other between the particles so that the movement of particles to be inhibited (Table IV).

\begin{tabular}{|l|l|l|l|l|l|}
\hline 150 & $\begin{array}{l}\text { Elemen } \\
\text { number }\end{array}$ & $\begin{array}{l}\text { Elemen } \\
\text { symbol }\end{array}$ & $\begin{array}{l}\text { Elemen } \\
\text { name }\end{array}$ & $\begin{array}{l}\text { Atomic } \\
\text { concentration }\end{array}$ & ErrorVolume 29 Issue 3 (2018) \\
\hline \multirow{2}{*}{ NCS } & 8 & 0 & Oxygen & 85,1 & 0,2 \\
\cline { 2 - 6 } & 6 & $\mathrm{C}$ & Carbon & 14,9 & 0,7 \\
\hline
\end{tabular}


Table IV. Flow properties of starch

\begin{tabular}{lcccc}
\hline Material & $\begin{array}{c}\text { Flow velocity } \\
(\mathbf{s e c} / \mathbf{1 0 0 g}) *\end{array}$ & $\begin{array}{c}\text { Angle of } \\
\text { repose }(\mathbf{0})\end{array}$ & $\begin{array}{c}\text { Tapped density } \\
(\mathbf{g} / \mathbf{m L})^{*}\end{array}$ & $\begin{array}{c}\text { Bulk density } \\
(\mathbf{g} / \mathbf{m L})^{*}\end{array}$ \\
\hline NCS & - & - & $0.624 \pm 0.006$ & $0.463 \pm 0.0006$ \\
CSFP & $6.23 \pm 0.15$ & $32.57 \pm 1.25$ & $0.793 \pm 0.007$ & $0.656 \pm 0.002$ \\
\hline
\end{tabular}

The sign (-) indicates the material cannot flow; The $\left(^{*}\right)$ indicates the result of measurement \pm Std Dev with $\mathrm{n}$ $=4$
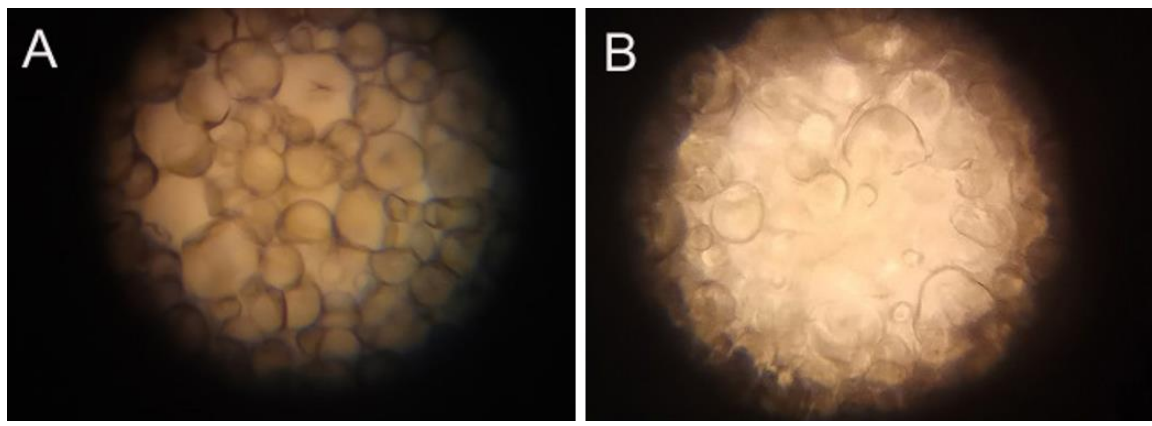

Figure 1. Microscopic starch A. Microscopic NCS with 40X magnification, B Microscopic CSFP with 40X magnification.

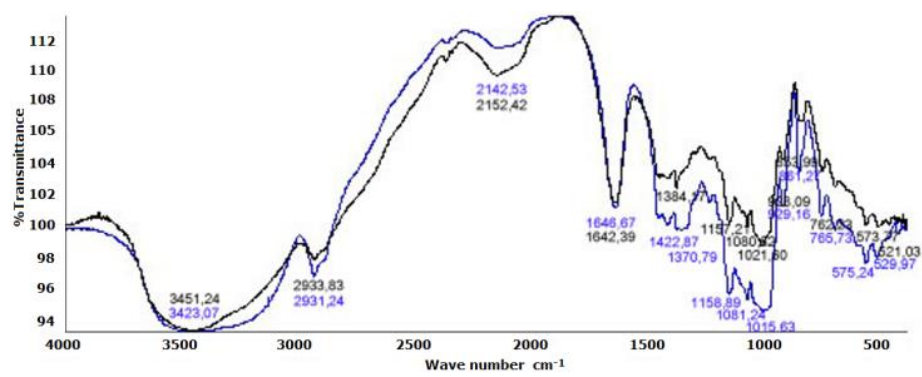

Figure 2 Fourier transform infrared (FT-IR) spectroscopy analysis

According to (Bahram et al., 2014), fines have a larger contact area between the larger particles, so the attraction force between the particles increases. This results in the speed of the flow, the more fines the flow rate decreases. In general, the resulting flow velocity and angle of repose have aligned with the difference in its mean diameter. Fully pregelatinized starch with large size has a large flow rate and reduce the density, better angle of repose, and vice versa. This is because the material with large diameter size has small surface area resulting in low cohesiveness and prevents the material to accumulate so that the flow is better, besides the bulk density value of the starch material is fully pregelatinized which is greater than the natural starch. Affect gravity causes the fully pregelatinized starch with a large weight to flow faster than the native starch with smaller weights.

\section{Qualitative testing}

Structural changes conformation by SEM

Native starch granules are oval in shape without any hollow area and heterogeneous distribution (Figure 1A). After modification treatment, starch granules were contorted to a folded structure, showed brief ringence and the hollow area inside the starch were observed, which confirmed the presence of a gelatinized granule. From the SEM images, it was observed that the structures of starches were modified. 

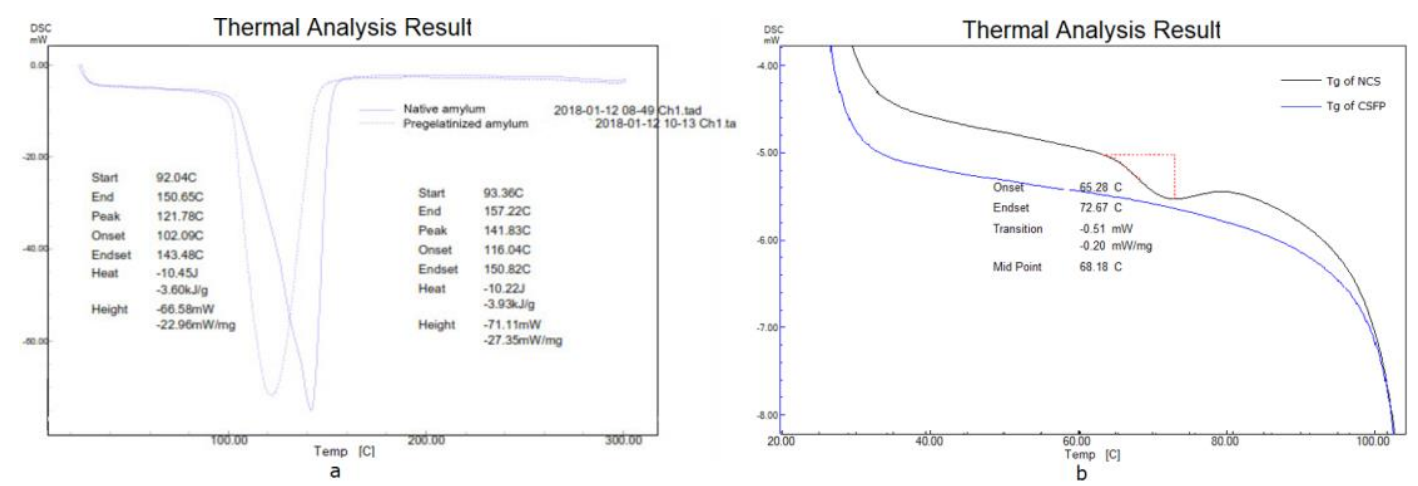

Figure 3a. DSC thermograms of NCS and CSFP b. Tg of NCS and Tg of CSFP

\section{Fourier transform infrared (FT-IR)}

Fourier transform infrared (FT-IR) spectra of NCS and CSFP (Figure 2. The infrared spectra of starch examination is used to detect functional groups. Each absorption at a given wavelength represents the presence of a specific functional group. The analysis results in the form of chromatogram signal of IR intensity relation to wavelength. On the NCS spectrum detected there is an $\mathrm{O}-\mathrm{H}$ function group at wave number $3423.07 \mathrm{~cm}^{-1}$, C-H at wave number $2931.24 \mathrm{~cm}^{-1}, \mathrm{C} \equiv \mathrm{C}$ at wave number $2142.53 \mathrm{~cm}$ ${ }^{1}, \mathrm{C}=\mathrm{O}$ at wave number $1646.67 \mathrm{~cm}^{-1}$. While in CSFP also detected $\mathrm{O}-\mathrm{H}$ group at wave number $3451.24 \mathrm{~cm}^{-1}, \mathrm{C}-\mathrm{H}$ at wave number $2933.83 \mathrm{~cm}^{-1}$, $\mathrm{C} \equiv \mathrm{C}$ at wave number $2152.42 \mathrm{~cm}^{-1}, \mathrm{C}=\mathrm{O}$ at wave number 1642.39. However, in CSFP this occurs the missing peak of the $\mathrm{C}-\mathrm{H}$ functional group at the wave number $1422.877 \mathrm{~cm}^{-1}$. So from the FT-IR analysis it can be concluded that the process of starch modification does not affect the chemical properties of starch.

\section{Differential Scanning Calorimetry (DSC)}

Thermal properties of NCS and CSFP were studied using DSC (Figures 3). Native cassava starch have shown melting endotherms at $141.83^{\circ} \mathrm{C}$ with normalized heat of fusion $3.93 \mathrm{~kJ} / \mathrm{g}$. Fully pregelatinized cassava starch showed an interesting change in the thermogram. The melting endotherm for fully pregelatinized cassava starch $121.78^{\circ} \mathrm{C}$, whereas diffused endotherm with low enthalpy was observed for fully pregelatinized. The early onset of the fully pregelatinized peak was due to its partial dissolution. Fully pregelatinized of cassava starch significantly affects the thermal properties of a polymer. The measurement of $\mathrm{Tg}$ with DSC (Figure 3B). Tgis the main characteristic transformation temperature of the amorphous phase, where at NCS it looks peak $\operatorname{Tg} 68.18^{\circ} \mathrm{C}$, which means NCS does not experience gelatinase and will experience gelatinase at temperature $68.18^{\circ} \mathrm{C}$. CSFP is not readable peak $\mathrm{Tg}$ means that in CSFP there is a physical change on starch, where starch already experienced full gelatinase.

\section{EDS analysis}

After being fired at the desired position, there would appear peaks on the starch representing an element contained. Seen the percentage of each element in the native starch and fully pregelatinized starch. Based on the figure 4 and table VI, analysis of native starch and fully pregelatinized starch using EDS revealed that some of the most abundant elements in percentage form are $\mathrm{O}$ with the average percentage of $83.65 \%$ and the second most element $\mathrm{C}$ at the average of $16.35 \%$.

\section{Correlation between physical properties and flowability indicators for CSFP}

The powder physical properties measured included the particle size, shape, density and flowability. Particle size was found to be an accurate predictor of powder flowability, with increasing particle size indicating well in the flow. Particle shape irregularity was found to be the main reason for lower flowability. Irregular particles tended to interlock with each other and resisted powder flow. Wide distributions of particle shapes and sizes were found to have an impact on powder flowability. Although CSFP consisted of a large number of elongated particles, it demonstrated good flowability. 

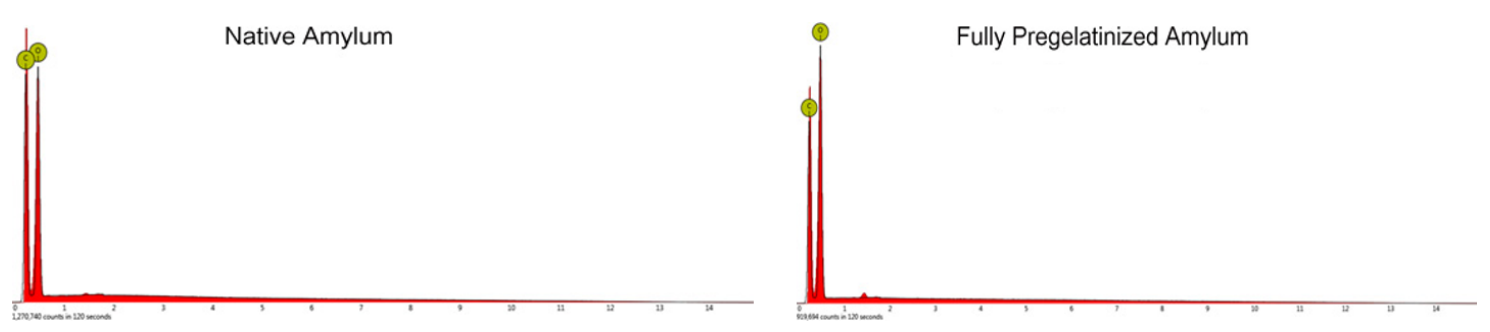

Figure 4. Graphic EDS of NCS and CSFP.

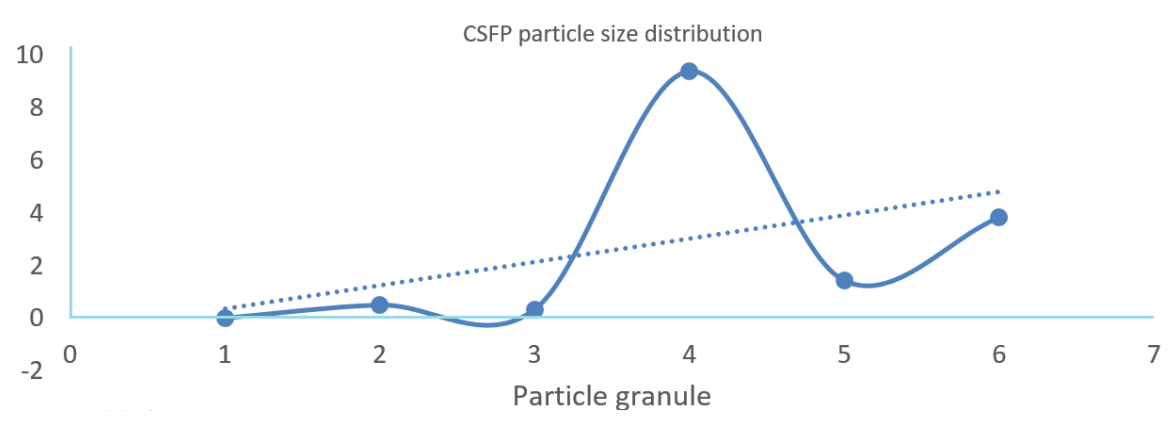

Figure 5. CSFP Particle distribution

Table V. Percentage of starch element

\begin{tabular}{lccccc}
\hline & Elemen number & Elemen symbol & Elemen name & Atomic concentration & Error \\
\cline { 2 - 6 } NCS & 8 & O & Oxygen & 85.1 & 0.2 \\
& 6 & $\mathrm{C}$ & Carbon & 14.9 & 0.7 \\
CSFP & 8 & $\mathrm{O}$ & Oxygen & 82.2 & 0.2 \\
& 6 & $\mathrm{C}$ & Carbon & 17.8 & 0.7 \\
\hline
\end{tabular}

This was because of the fact that CSFP bulk consisted of small spherical particles in addition to elongated particles, which appeared to assist powder flow (Figure 5.)

\section{In vitro evaluation of the prepared tablets CSFP and NCS \\ Tablet weight variation}

Twenty tablets were randomly selected and accurately weighed. Results are expressed as mean values \pm SD. The average weight of 20 tablets along with standard deviation of entire formulations (Table VII). The percentage of weight variation of individual tablets from the average weight was found to be within $\pm 7.5 \%$ $(\mathrm{w} / \mathrm{w})$ which proved that the entire tablets have passed the USP weight variation test.

\section{Hardness test}

For each formulation, the hardness of six tablets was determined individually using a hardness tester. The hardness of tablets of entire batches was found $5.21 \pm 1.67 \mathrm{~kg} / \mathrm{cm}^{2}$ for NCS and $8.52 \pm 0.231 \mathrm{~kg} / \mathrm{cm}^{2}$ for CSFP.

\section{Tablet friability}

According to the USPNF23, 10 tablets were randomly selected and placed in the drum of a tablet friability test apparatus. The drum was adjusted to rotate 100 times in $4 \mathrm{~min}$ then the tablets were removed from the drum, dedusted, and accurately weighed. The percent weight loss was calculated. The friability test of tablets of entire batches (Table VI). depicted that the tablets of entire batches had passed the USP criteria of friability testing $(0.5-1 \%, \mathrm{w} / \mathrm{w})$. The results revealed that tablets possess good mechanical strength.

\section{In vitro disintegration test}

As the disintegration time for the tablets formulated by using CSFP has increased than 
Table VI. Evaluation of physical properties of tablets (150mg) CSFP and NCS

\begin{tabular}{llll}
\hline Type of Testing & Limit requirements & NCS & CSFP \\
\hline Size $(\mathrm{mm})$ & $*) 1 / 3-2 / 3$ diameter & $3.45 \pm 0.09$ & $3.274 \pm 0.04$ \\
$\begin{array}{l}\text { Weight variation test } \\
(\mathrm{mg})\end{array}$ & $* *)$ it can be acceptable if the batch falls & $151.56 \pm 0.03$ & $153.84 \pm 0.05$ \\
Hardness $\left(\mathrm{kg} / \mathrm{cm}^{2}\right)$ & $*$ within the $\pm 7.5 \%$ of Std Dev & & \\
Friability $(\%)$ & $* *)$ loss in weigh less than $0.5-1 \%$ & $5.21 \pm 1.67$ & $8.52 \pm 0.231$ \\
Invitro disintrgration & $*$ ) No more than 15 minutes for non- & $0.541 \pm 0.06$ & $0.335 \pm 0.09$ \\
test (s) & coated tablet & & \\
\hline
\end{tabular}

* Indonesia pharmacopoeia V (2014); ** USPNF23 indicates the result of measurement \pm Std Dev with $n=5$

TableVII. Dissolution Studies

\begin{tabular}{ccc}
\hline Time (mins) & CSFP (\%) & NCS (\%) \\
\hline 10 & 11.5 & 20.2 \\
20 & 14.6 & 36.7 \\
30 & 23.1 & 52.5 \\
40 & 28.8 & 64.9 \\
50 & 34.5 & 75.7 \\
60 & 41.7 & 88.3 \\
\hline
\end{tabular}

that of NCS. It is concluded that the binding capacity of CSFP would be many times greater than that of NCS. From the test results of tablet preparations (Table VI.), CSFP is suitable for sustain released tablet because it is able to keep the tablet from being disintegration more than $2 \mathrm{~h}$ of testing time, while for NCS it is suitable for conventional tablets.

\section{Dissolution test}

The dissolution test was carried out by using the USP type II method (paddle method). The beaker is immersed in the water bath of temperature $37^{\circ} \mathrm{C}$. It is filled with $900 \mathrm{~mL}$ of $\mathrm{HCl}$ $0.1 \mathrm{~N}$ and the apparatus was set at $75 \mathrm{rpm}$. The samples were taken in the interval of 10 minutes and estimate the content by spectrophotometer at $320 \mathrm{~nm}$. The same procedure was repeated at different time intervals and absorbance was noted and the percentage drug release was calculated (Sulaiman, 2011). From dissolution study of ranitidine $\mathrm{HCl}$ tablets formulated by using NCS has increased release than that of CSFP (Table VII).

\section{CONCLUSION}

It can be concluded that there are differences of physical and chemical characteristics of native cassava starch and cassava starch fully pregelatinized. CSFP as a method produces a good profile starch contained a higher amount of amylose with larger particle size and greater good the particle density and viscosity than the natural starch and improve its flow properties and compatibility, CSFP has a noticeable effect on fragility, hardness, disintegration time and percentage of drug release from the tablets produced. The percentage of drug release shows that CSFP has a large influence on the binding strength of the tablet. Further studies on this starch as a filler on sustain release tablets will provide further information needed to establish the usefulness of this starch in tablet manufacturing.

\section{ACKNOWLEDGEMENT}

This study work supported by LPDPBUDI, UPT Forensik Udayana University. This paper is based, in part, on the work done for a Doctoral. The degree from Gadjah Mada University, Yogyakarta.

\section{REFERENCES}

Achor M., Oyeniyi J., Musa M., Gwarzo M., 2015. Physicochemical Properties of 
Cassava Starch Retrograded in Alcohol. J. Appl. Pharm. Sci.; 126-131.

Adedokun MO., Itiola OA., 2011. Disintegrant activities of natural and pregelatinized trifoliate yams, rice and corn starches in paracetamol tablets. J. Appl. Pharm. Sci.; 1, 2.

Abdorreza MN., Robal M., Cheng LH., Tajul, AY., Karim AA.,, 2012. Physicochemical, thermal, and rheological properties of acid-hydrolyzed sago (Metroxylon sagu) starch, Food Sci. Technol.; 46, 135-141.

Cahyana A., Marzuki A., 2014. Analisa SEM (Scanning Electron Microscope) Pada Kaca TZN Yang Dikristalkan Sebagian. Jur. Ilmu Fis. Pasca Sarj. Univ. Sebel. Maret 23.

Ansel, 2011. Pharmaceutical Dosage Form and Drug Delivery Systems, ninth. ed, ninth edition. university of Georgia.

Anwar E., Yusmarlina D., Rahmat H., 2006. Phosphorylation of pregelatinized maranta starch (Maranta arundinaceae L.) as theophylline tablet matrix controlled release. Indonesia. J. Pharm.; 37-44.

Bahram HR., Hassan-Beygi SR., Kianmehr, MH., Valaei I., Mazraeh, HM., 2014.The effect of moisture content, particle size and consolidation stress on flow properties of vermicompost. Agric. Eng. Int. CIGR J.; 16, 247-252.

Bestari AN., Hidayatullah R., Sulaiman TNS., 2016. Pembuatan Amilum Sagu (Metroxylon sagu, Rottb.) Pregelatin Dan Material Komposit Sebagai Filler-Binder Sediaan Tablet.

Bhardwaj TR., Kanwar M., Lal R., and Gupta A., 2000. Natural Gums and Modified Gums as Sustained-Release Carriers, Drug Dev. Ind. Pharm.; 26(10), 1025 - 1038.

Carstensen JT., Chan PC., 1997. Flow Rate And Angle Of Repose Wet Processed Granulations, J. Pharm. Sci.; 66, p.12351238

Dreu R., Toschkoff G., Funke A., Altmeyer A., Knop K., Khinast J., Kleinebudde P., 2016. Evaluation of the tablets' surface flow velocities in pan coaters. Eur. J. Pharm. Biopharm.; 106, 97-106.

Eckelman CA., 1998. The shrinking and swelling of wood and its effect on furniture.
Purdue University Cooperative Extension Service.

El-Mallawany R., Abdallah MD., Ahmed IA., 2008. New Tellurite Glass: Optical Properties., Journal Material Chemistry and Physics. Elsevier.; 109, 291-296.

Emami J., Tavakoli N., 2004. Formulation of Sustained-Release Lithium Carbonate Matrix Tablets: Influent of Hydrophilic Material on The Release Rate and In Vitro-In Vivo Evaluation, J Pharm Pharmaceut Sci.; 7(3) ,338-344.

Fanani Z., Miksusanti M., Desnelli D., 2010. Biodegradation of Polyblend Polypropilene-Palm Oil-Amylum BY Bacillus subtilus And Clostridium botulinum. Indones. J. Chem.; 3, 160-165.

Gaikwad A., Tamizhrasi S., Sorti A., Gavali P., Mehare G., 2010. Formulation In Vitro Characterization of Polymethacrylic Acid Nanoparticle Containing Furosemide. Int J. Pharm Res.; 2(1), 300-304.

Gusnimar A., 2003. Teknik Analisis Kadar Amilosa Dalam Beras. Bul. Tek. Pertan; 8, 82-84.

Hadi MA., Raghavendra RNG., Srinivasa RA., 2016. Formulation and evaluation of ileocolonic targeted matrix-mini-tablets of Naproxen for chronotherapeutic treatment of rheumatoid arthritis. Saudi Pharm. J.; 24, 64-73.

Hareesh, BK., Mohammed, G.A., Narayana, C.R., 2012. Development And Evaluation Of In Situ Gels Of Moxifloxacin For The Treatment Of Periodontitis. Indonesian J. Pharm.; 23(3), 141-146.

Hastuti M., 2009. Pengaruh Perbedaan Suhu Dalam Metode Pembuatan Amilum Singkong Pregelatinasi Terhadap Sifat Fisik Tablet Chlorpheniramine Maleate Secara Kempa Langsung. Universitas Muhammadiyah Surakarta.

Horwitz W., AOAC International (Eds.), 2006. Official methods of analysis of AOAC International, 18. ed., current through rev. 1. ed. AOAC International, Gaithersburg, $M d$.

Indonesian Pharmacopeia, 2014. Indonesia Pharmacopeia, V. ed. Indonesia.

Juliano BO., 1971, A simplified assay for milded rice amylose. Cereal Science Today, 16, 334360 
Kemp SE., Hollywood T., Hort J., 2009. Sensory evaluation: a practical handbook. Ames, Iowa : Wiley-Blackwell, Chichester, U.K, Krisyanella K., Susilawati N., Rivai H., 2017. Pembuatan Dan Karakterisasi Serta Penentuan Kadar Flavonoid Dari Ekstrak Kering Herba Meniran (Phyllantbus niruri L.).

Mariyani KA., Arisanti CIS., Setyawan EI., 2012.Pengaruh Konsentrasi Amilum Jagung Pregelatinasi Sebagai Bahan Penghancur Terhadap Sifat Fisik Tablet Vitamin E Untuk Anjing. J. Farm. Udayana, 1.

Octavia MD., Halim A., Indriyani R., 2017. Pengaruh Besar Ukuran Partikel Terhadap Sifat-Sifat Tablet Metronidazol.

Olowosulu AK., Oyi A., Isah AB., Ibrahim MA., 2011, Formulation and evaluation of novel co-processed excipients of maize starch and acacia gum (StarAc) for direct compression tableting. Int. J. Pharm. Res. Innov, 2, 39-45.

Onyango C. Mewa EA., Mutahi AW.; dan Okoth MW, 2013. Effect of heatmoisture-treated cassava starch and amaranth malt on the quality of sorghumcassava-amaranth bread. African Journal of Food Science.,7(5):80-86.

Parwiyanti FP., Wijaya A., Malahayati N., Lidiasari E., 2015. Swelling Power Dan Kelarutan Pati Ganyong (Canna edulis, Kerr.) Termodifikasi Melalui HeatMoisture Treatment Dan Penambahan Gum Xantan Untuk Produk Roti.

Patel VF., Patel NM., 2006. Intragastric floating drug delivery system of cefuroxime axetil: in vitro evaluation. AAPS PharmSciTech.,7, E118-E124.

Piotrowski D., Golos A., Grzegory P., 2014. Shrinkage and mechanical properties of defrosted strawberries dried by convective, vacuum and convectivevacuum methods. Acta Agrophysica 21.

Piyachomkwan K, Chotineeranat S., Kijkhunasatian C., Tonwitowat R., Prammanee S., Oates CG., Sriroth, K., 2002. Edible canna (Canna edulis) as a complementary starch source to cassava for the starch industry. Industrial Crops and Products; 16:11-21.

Qazi, IM., Rakshit SK., Tran T., Ullah J., Khan Z., 2014. Effect of blending selected tropical starches on pasting properties of rice flour. Sarhad j. Agric., 30(3):357-368.

Shastri DH., Patel LD., Parikh RK., 2010, Studies on In situ hydrogel: A smart way for safe and sustained ocular drug delivery. J. Young Pharmacist:;2(2):116-120.

Sholihah Z., Noer ER., 2014. Analisis Kandungan Zat Gizi Dan Daya Terima Makanan Enteral Berbasis Labu Kuning Dan Telur Bebek. J. Nutr. Coll.,3, 855861.

Siswanto A., Soebagyo SS. 2006, Optimasi formula sediaan tablet lepas lambat teofilin dengan bahan matrik HPMC, $\mathrm{Na}$ CMC, dan xanthan gum. Maj. Farm. Indonesia, 17.

Sulaiman TNS., Fudholi A., Nugroho AK.,., 2011, Optimasi Formula Tablet Gastroretentive ranitidine $\mathrm{HCl}$ dengan system floating. Majalah Farmasi Indonesia, 22(2), $106-114$.

United States Pharmacopeial Convention, 2014. The United States Pharmacopeia: the national formulary.

Williams PCK., 1958. A Rapid Colorimetric Procedure for Estimating the Amylose Content of Starch and Flour,

Wlodarski K., Tajber L., Sawicki W. 2016. Physicochemical properties of direct compression tablets with spray dried and ball milled solid dispersions of tadalafil in PVP-VA. Eur. J. Pharm. Biopharm.,109, 14-23.

Yusif RM., Hashim IIA., Mohamed EA., El Rakhawy MM., 2016. Investigation and evaluation of an in situ interpolymer complex of carbopol with polyvinylpyrrolidone as a matrix for gastroretentive tablets of ranitidine hydrochloride. Chem. Pharm. Bull. (Tokyo), 64, 42-51.

Yusuf H., Radjaram A., Setyawan D., 2008, Modifikasi pati singkong pregelatin sebagai bahan pembawa cetak langsung. $J$ Penelit Med Eksakta, 7, 31-47. 